\title{
EDITORIAL
}

\section{Microplastics and their fate in Marine Environment: A review}

\author{
Dr. Nishantha K. Kalutharage \\ Senior Lecturer GI, Department of Chemistry University of Ruhuna
}

\begin{abstract}
Microplastic (MP) is a collective term to describe a heterogeneous mixture of plastic particles ranging in size from a few microns to several millimetres in diameter. MPs are pollutants threatening the marine environment globally. Plastics released to the environment, over time, will be exposed to weathering, sunlight, and mechanical degradation, large plastics will become brittle and break down into secondary microplastic or MPs can be released directly from cosmetics and personal care products. These MPs are composed of several plastic types and can be affected on marine environment (primary MP), not only by itself but also by accumulating other pollutants such as heavy metals and organic pollutants.
\end{abstract}

Keywords: Microplastics, MP, Marine Ecosystem, Pollution

\section{Introduction}

Plastic pollution threatens the marine environment globally. The industrial revolution paved the way for the rapid development in manufacturing of longlasting plastic materials. Due to the reason that the amount of plastic waste produced has increased unlimitedly. Thompson et al., 2009 has named this plastic era as "the plastic age". Plastics release to environment by littering, ineffective recycling management practices, weather events, etc., it has been estimated that approximately 4.4 to 12.7 million tons of plastic enter the marine environment annually (Jambeck et al., 2015).

Over time, in the environment plastics are exposed to weathering, sunlight, and mechanical degradation in the environment, large plastics will become brittle and break down to secondary microplastics (MPs) $(<5$ $\mathrm{mm})$ and nano plastics $(<100 \mathrm{~nm})$ (Prinz \& Korez, 2020). Term "Microplastic" is used as a collective term to describe a heterogeneous mixture of particles ranging in size from a few microns to several millimeters in diameter; including particles of various shapes from completely spherical to elongated fibres (Thompson, 2015).

MPs categorize into two forms: primary MP and secondary MP. Primary MPs are small particles designed to be used for manufacturing large plastic items, including virgin resin pellets and microbeads (from cosmetics and personal care products) (Andrady, 2017). Secondary MPs also include microfibers that are washed out of synthetic clothes (Browne et al., 2013). Many fibres and microbeads can be passed through the filters used in water treatment plants and sewage systems and be released into the ocean (Carr et al., 2016; Edo et al., 2020; Lebreton et al., 2017).

Nowadays, MPs are widespread in marine environment including estuaries, shorelines, ocean surface, water column, and the seafloor. Due to the reason that MPs are spread over all environments they can interact with marine animals in any zone of marine ecosystem and in any tropic level. The bioavailability

*corresponding author: knishantha@chem.ruh.ac.lk (iD https://orcid.org/0000-0003-1783-4530 
of microplastics in a given zone depends on their physical properties such as density, crystallinity and the colour (Wright et al., 2013).

\section{Sources and formation of microplastics:}

Microplastics can be categorized into two groups based on the origination: (i) Primary: Small particles directly released as pellets or powders; (ii) Secondary: Resulted from fragmentation of larger items (Guo \& Wang, 2019). Particles which are of microplastic-size are directly used in a wide range of applications such as plastic pellets $(\sim 5 \mathrm{~mm}$ diameter $)$ and powders $(<0.5$ $\mathrm{mm})$, which are used as a feedstock for the production of larger items. These pellets have been originated from industrial spillage. Small plastic particles around $0.25 \mathrm{~mm}$ are also widely used as abrasives in cosmetic products and as an industrial abrasive. MPs from cosmetics and cleaning agents (microbeads) are carried with the wastewater, via sewers. These beads are not removed effectively by sewage treatment, and hence are accumulating in the ocean environment. Also larger items of plastic debris will become brittle under the action of ultraviolet (UV) light and heat and then fragment due to physical action from wind and waves (Andrady, 2017).

Plastics in the marine environments undergo various weathering/aging processes, such as solar exposure, thermal aging, bio-film growth, and oxidation (Figure 1, Andrady, 2017). This results in the degradation of plastics polymers. Degradation refers to a series of chemical reactions that breaks the structures of plastics polymers. The degradation can be classified into (i) photodegradation, (ii) thermal degradation, (iii) biodegradation and (iv) thermos-oxidative degradation, based on the different weathering processes. Introduction of secondary MPs into environments is caused by the degradation and the fragmentation of macroscopic plastics waste. For primary and secondary MPs, degradation mainly changes their physical and chemical properties, such as colour, surface morphology, crystallinity, particles size, and density (Guo \& Wang, 2019).

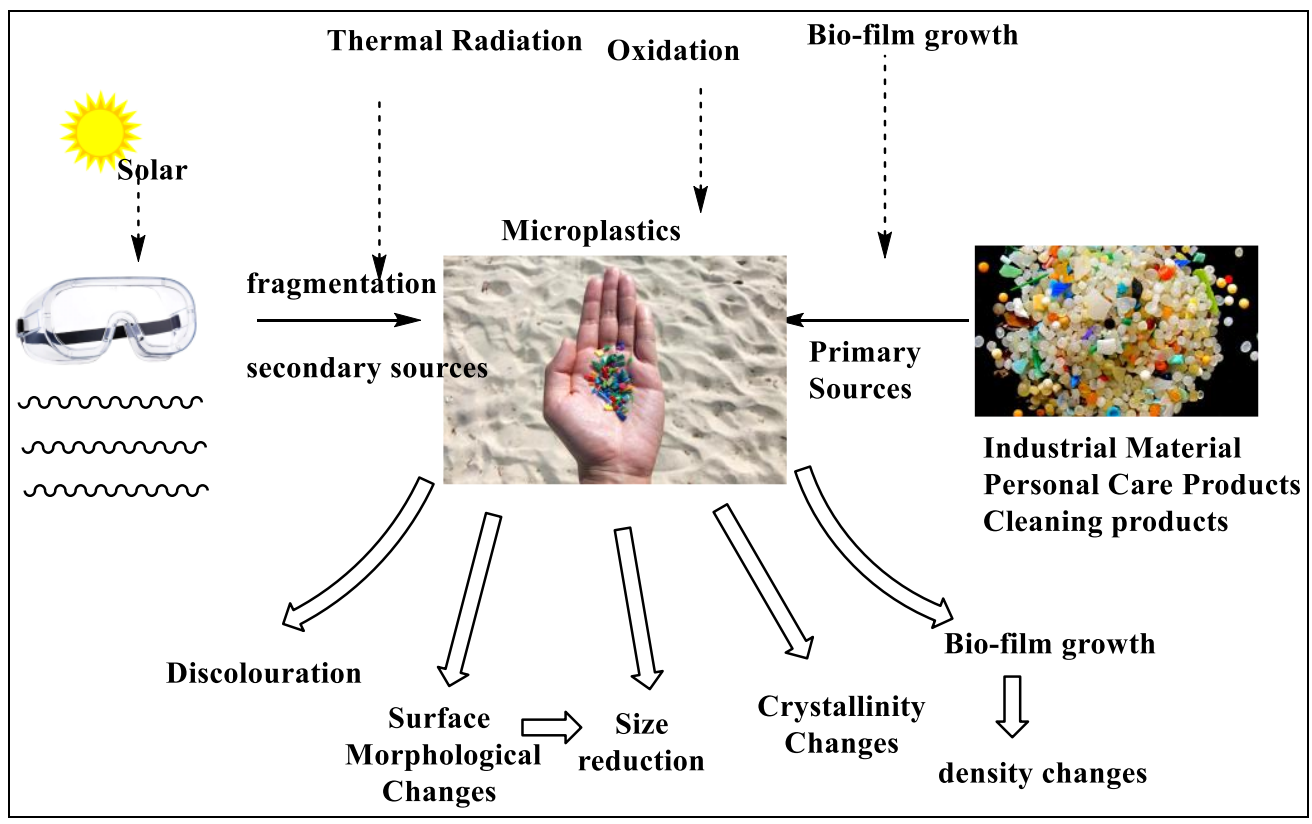

Figure 1: Changes in Properties of MPs after degradation (Guo \& Wang, 2019) 


\section{Formation of secondary microplastics:}

Degradation is a chemical change that drastically reduces the average molecular weight of the polymer. Those degraded plastics become brittle enough to fall apart into powdery fragments on handling known as secondary microplastics. Even these fragments, often invisible to the naked eye, can undergo further degradation via microbial-mediated biodegradation with the carbon in polymer being converted into $\mathrm{CO} 2$ (and incorporated into marine biomass). When this process goes onto completion and all the organic carbon in the polymer is converted, it is referred to as complete mineralisation (Eubeler et al., 2009).

Degradation is generally classified as (a) Biodegradation- action of living organisms usually microbes, (b) Photodegradation - action of light (usually sunlight in outdoor exposure), (c) Thermooxidative degradation - slow oxidative breakdown at moderate temperatures, (d) Thermal degradation - action of high temperatures, and (e) Hydrolysis - reaction with water.
With common polymers such as LDPE, HDPE, PP and nylons exposed to the marine environment it is primarily the UV-B radiation in sunlight that initiates photo-oxidative degradation. Once initiated, the degradation can also proceed thermooxidatively for some time without the need for further exposure to UV radiation.

\section{Composition of MPs and properties:}

The main constituents of MPs found in marine environments are polyethylene (PE), polypropylene (PP), and polystyrene (PS), polyvinyl chloride (PVC), polyamine (PA), and Polyethylene terephthalate (PET). The properties and common uses of these MPs polymers are listed in Table 1 (Driedger et al., 2015). The degree of crystallinity refers to the proportion of crystalline regions in polymers, where the polymer chains are aligned with each other. Amorphous polymers are soft and flexible and exhibit poor strength and poor fatigue resistance and the amorphous resins of polymers include glassy domains and rubbery domains.

Table 1: Properties of polymer types and common uses of identified plastics (Driedger et al., 2015)

\begin{tabular}{|c|c|c|}
\hline Plastic polymer type & Density $\left(\mathrm{g} / \mathrm{cm}^{3}\right)$ & $\begin{array}{l}\text { Plastic Item/s With Particular } \\
\text { Polymer Type }\end{array}$ \\
\hline Expanded Polystyrene(EPS) & $0.01-0.04$ & $\begin{array}{l}\text { Foam cups, plates, trays, clamshell } \\
\text { containers }\end{array}$ \\
\hline Polypropylene(PP) & $0.85-0.92$ & $\begin{array}{l}\text { Auto parts, food containers, } \\
\text { dishware, bottle caps, straws }\end{array}$ \\
\hline Low-Density Polyethylene(LDPE) & $0.89-0.93$ & $\begin{array}{l}\text { Container lids, six-pack holders, } \\
\text { squeeze bottles, tubing, diapers, } \\
\text { shotgun shells }\end{array}$ \\
\hline High-Density Polyethylene(HDPE) & $0.94-0.98$ & $\begin{array}{l}\text { Detergent and household cleaner } \\
\text { bottles, milk jugs, grocery bags, } \\
\text { recycling bins, buoys }\end{array}$ \\
\hline Acrylonitrile-Butadiene-Styrene(ABS) & $1.04-1.06$ & Electronic equipment casing, pipes \\
\hline Polystyrene(PS) & $1.04-1.08$ & $\begin{array}{l}\text { Plates, cutlery, optical disk cases, } \\
\text { toys }\end{array}$ \\
\hline Polyamide (Nylon)(PA) & $1.13-1.16$ & $\begin{array}{l}\text { Toothbrush bristles, fishing line and } \\
\text { nets, rope }\end{array}$ \\
\hline Polymethyl Methacrylate (acrylic)(PMMA) & $1.16-1.20$ & $\begin{array}{l}\text { Optical lenses, paint, shatterproof } \\
\text { windows }\end{array}$ \\
\hline Polycarbonate(PC) & $1.20-1.22$ & Optical disks \\
\hline Cellulose Acetate(CA) & 1.30 & Cigarette filters \\
\hline Polyethylene terephthalate (polyester)(PET) & $1.38-1.41$ & $\begin{array}{l}\text { Textiles, soft drink and water } \\
\text { bottles, strapping }\end{array}$ \\
\hline
\end{tabular}




\section{Polyvinyl chloride(PVC)}

Polytetrafluoroethylene(PTFE)

MPs are distributed all zones of water column based on their density. In principle, plastics with densities greater than $1 \mathrm{~g} / \mathrm{cm}^{3}$ should sink in water (HidalgoRuz et al., 2012). The density of PVC, PS, PET, and PA are greater than $1 \mathrm{gcm}^{-3}$, so they are inclined to sink in the water column. PE and PP are floating on water due to their densities which is $<1 \mathrm{gcm}^{-3}$. When the

\section{$1.38-1.41$}

2.10-2.30
Pipes, fencing, shower curtains, flooring, plastic wrap, tampon applicators Wires, cables, bearings, gears

Table 2: Key material characteristics of the plastics that influence on the behaviour of their microplastic particles (adopted from Andrady, 2017)

\begin{tabular}{lll}
\hline Characteristic & Influence on behaviour of MPs & $\begin{array}{l}\text { Comments and Possible } \\
\text { Modifications }\end{array}$ \\
\hline Density & Buoyancy in seawater determines where in the & $\begin{array}{l}\text { Density ranges of classes of plastics } \\
\text { are generally known but can be }\end{array}$ \\
water column the MP is likely to initially reside & modified by fillers as well as by \\
in & & surface foulants
\end{tabular}

\begin{tabular}{ll}
\hline Partial crystallinity & $\begin{array}{l}\text { The degree of crystallinity determines the ease } \\
\text { of oxidative degradation and fragmentation } \\
\text { during weathering }\end{array}$
\end{tabular}

General ranges of values are available for different plastics but these can change based on sample history

$\begin{array}{lll}\begin{array}{l}\text { Oxidation } \\ \text { resistance or } \\ \text { weathering ability }\end{array} & \begin{array}{l}\text { Chemical structures determine how easily } \\ \text { oxidizable the plastic will be in the } \\ \text { environment. Fragmentation is a consequence } \\ \text { of extensive oxidative degradation }\end{array} & \begin{array}{l}\text { Ease of oxidation suggested by the } \\ \text { chemical structure may be very } \\ \text { different in compounded plastics that } \\ \text { incorporate stabilizers and additives }\end{array}\end{array}$
Biodegradability Determines the rate of mineralization and potential partial removal of plastics from the water column or sediment
Common plastics are generally bio- inert. Exceptions do exist in synthetic plastics as well as biopolymers.

\section{Residual monomer Toxicity of leaching residual monomers in MPs to marine organisms that ingest plastics}

Both residual monomer levels in common plastics as well as their toxicities are reliably known.
Transport props. Bioavailability of residual monomers, additives and POPs sorbed by the MPs depends on their leaching rates in the gut environment
These properties are known for virgin resins but can change because degree of crystallinity can be varied by sample history or additives 


\section{Additives Concentration and toxicity of additives in MPs Chemistry, levels of use in plastics and may contribute to the adverse impacts on toxicities, are generally known. But ingesting species these levels for endocrine disruptors is not reliably known.}

Surface properties Rate of fouling of floating debris determines rates of weathering and sinking of MPs
Surface properties and fouling rates for common plastics are known.

\section{Accumulation of pollutants on MPs:}

MPs are not only pollutant by itself but also, they can accumulate other pollutants such as heavy metals ions and organic pollutants from surrounding water due to their small size, large specific area, and hydrophobic nature. Research have shown that the concentrations of metals on MPs are distinct in different sampling locations. This is due to industrialization of the sampling locations and the presence of anthropogenic activities. Different MPs types have unique sorption affinities for the same pollutants, based on the differences in the rubbery domains, the polarity, and the functional groups of MPs (Guo \& Wang, 2019).

The organic pollutants which accumulate on MPs are Polycyclic Aromatic Hydrocarbons (PAHs), Polychlorinated Biphenyls (PCBs), Hexachlorocyclohexanes (HCHs), and Dichlorodiphenyltrichloroethane (DDTs). The concentrations of these pollutants on MPs in environments are depend on factors such as the concentrations and types of pollutants, the environmental conditions in surrounding water, and the properties of MPs (Guo \& Wang, 2019). The abundance of the rubbery domains of MPs plays a major role in the sorption of organic compounds. The rubbery domains have high mobility, and high accessibility to some kinds of organic pollutants. PE has the highest abundance rubbery domains among MPs which makes it absorb organic pollutants such as lubricant oil, PCBs, and DDT. The special groups of MPs influence the interactions between MPs and polar compounds (Guo \& Wang, 2019). For example, the polar polymer PA with amide group demonstrates higher sorption capacities for polar antibiotic ciprofloxacin, amoxicillin, and tetracycline than other MPs (Li et al., 2018).
The properties of MPs play an important role in the sorption process. The sorption capacities of MPs increase with decrease of particles size mainly due to the large specific surface areas of small particles. The effect of particles size is less important than the specific surface area and the MPs types. MPs with rough surface, irregular shape and porous structure would have large specific surface area, and high sorption affinities for pollutants. The weathering/aging process causes the degradation in MPs, and therefore leads to the morphological changes, such as the formation of cracks and flakes on the surface of MPs (Guo \& Wang, 2019). Accordingly, the specific surface areas of MPs increase because of degradation. Evidence suggests that the aged MPs had higher sorption affinities for pollutants than the virgin ones (Müller et al., 2018).

\section{Distribution of microplastics}

Nowadays, MPs are widespread in marine environment including coastal ecosystems such as estuaries, on shorelines, the ocean surface or in the water column, and on the seafloor. Due to the reason that MPs are widely distributed over all environments, those can interact with marine animals representing any tropic level in any zone of marine ecosystem. The bioavailability of microplastics in a given zone depends on their physical properties such as density, crystallinity and colour (Wright et al., 2013).

\section{Impact of MPs on the marine organisms:}

MPs in the marine environments could be ingested by marine organisms, such as zooplankton, mussels, oysters, corals, fish, turtles, and even seabirds (Guo \& Wang, 2019). Three types of consequences of MPs 
uptake through the digestive tract or the respiratory system have been identified: (1) physical penetration of microplastic particles into cellular structures, (2) leaching of chemical additives or persistent organic pollutants (POPs) into the body, or (3) infection from eukaryotic and bacterial microbiota from the surface of ingested MPs. Fate of MPs in marine biota summarized in Fig. 2. Studies that are reported on microplastic effects on marine biota are summarized in the Table 3.

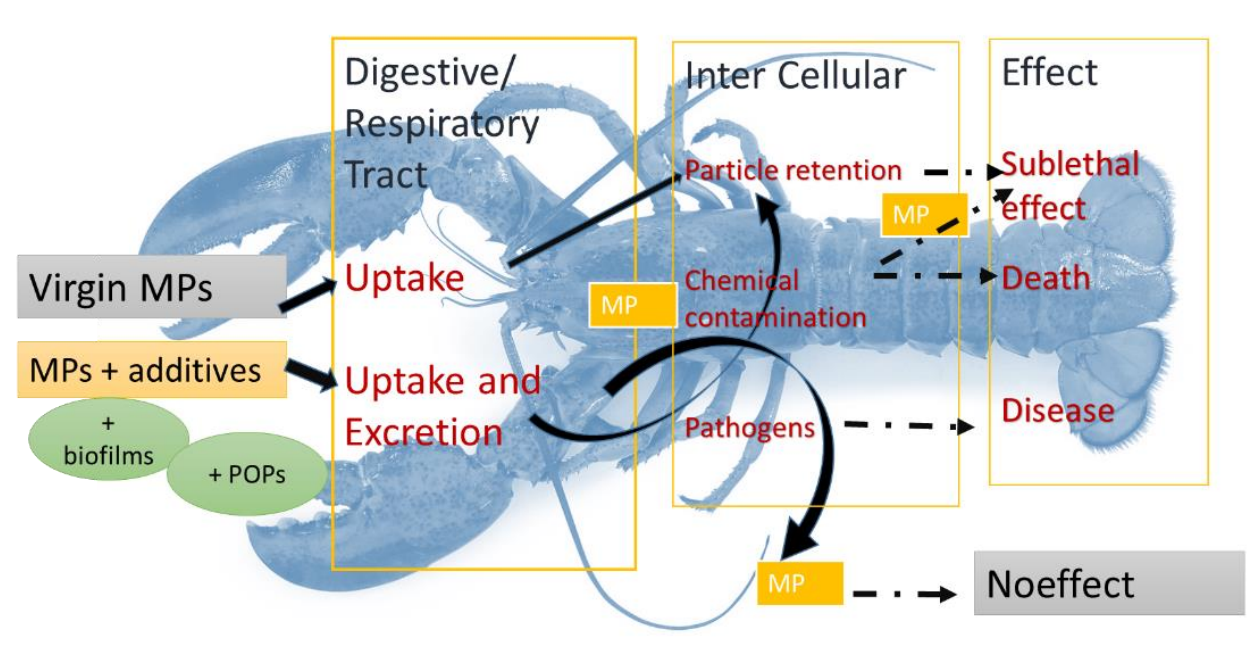

Figure 2: Fate of MPs in marine biota (adapted from Prinz \& Korez, 2020)

Table 3: Published studies that investigated microplastic effects on marine biota

\begin{tabular}{|c|c|c|}
\hline Name of biota & Ecological Effect & Reference \\
\hline Marine microalgae & Altered growth of algae & (Sjollema et al., 2016) \\
\hline Copepod & $\begin{array}{l}\text { Reduced feeding efficiency of prey of copepods, } \\
\text { energy depletion }\end{array}$ & (Cole et al., 2015) \\
\hline Lugworm & $\begin{array}{l}\text { Diminished ability to engineer sediment burrows and } \\
\text { removal of pathogenic bacteria, mortality, disrupt the } \\
\text { ecophysiological function }\end{array}$ & (Browne et al., 2013) \\
\hline $\begin{array}{l}\text { Peppery furrow } \\
\text { shell clam }\end{array}$ & $\begin{array}{l}\text { Neurotoxicity, mechanical injury to gills, MPs- } \\
\text { adsorbed BaP and PFOS exerting a negative influence } \\
\text { over the assessed biomarkers in this gills tissue }\end{array}$ & (O’Donovan et al., 2018) \\
\hline $\begin{array}{l}\text { European flat } \\
\text { oyster, Blue mussel }\end{array}$ & $\begin{array}{l}\text { Altered algal filtration rates affecting concentrations } \\
\text { and fluxes of benthic inorganic nitrogen }\end{array}$ & (Green et al., 2017) \\
\hline $\begin{array}{l}\text { peppery furrow } \\
\text { shell clam, } \\
\text { Scrobicularia plana }\end{array}$ & $\begin{array}{l}\text { Mechanical injury of gills caused by ingestion of } \\
\text { microplastics. The digestive gland affects by } \\
\text { mechanical damage caused by virgin microplastic } \\
\text { exposure }\end{array}$ & (O’Donovan et al., 2018) \\
\hline corals & the potential to be sub-lethal in the long term & (Reichert et al., 2018) \\
\hline $\begin{array}{l}\text { Crucian carp, } \\
\text { Bleak, Rudd Trench } \\
\text { pike and Atlantic } \\
\text { salmon }\end{array}$ & $\begin{array}{l}\text { Consumption of nanoparticle-containing zooplankton } \\
\text { affects the feeding behaviour of the fish }\end{array}$ & (Cedervall et al., 2012) \\
\hline
\end{tabular}




\begin{tabular}{lll}
\hline $\begin{array}{l}\text { Benthic scavengers } \\
\text { e.g. the crustacean } \\
\text { Nephrops norvegicus }\end{array}$ & $\begin{array}{l}\text { Fibrous microplastics have been found to accumulate } \\
\text { in marine sediments; gut content analysis has shown } \\
\text { plastic microfibers are being ingested in the } \\
\text { environment; ingestion is passive via food it scavenges } \\
\text { or sediment. }\end{array}$ & \\
\hline $\begin{array}{l}\text { Beach hoppers, } \\
\text { Frillfin goby }\end{array}$ & $\begin{array}{l}\text { No effect on boldness and } \\
\text { exploration variables in } \\
\text { fish behaviour }\end{array}$ & (Tosetto et al., 2017) \\
\hline Sea birds & $\begin{array}{l}\text { died emaciated after prolonged starvation } \\
\text { Sea turtles }\end{array}$ & $\begin{array}{l}\text { (Kühn \& van Franeker, 2012) } \\
\text { (Schuyler et al., 2014) }\end{array}$ \\
\hline Marine mammals sublethal effects & $\begin{array}{l}\text { Bioaccumulate in organisms producing sub-lethal } \\
\text { effects. }\end{array}$ & (Lusher et al., 2018) \\
\hline
\end{tabular}

\section{Conclusion}

This review analyses the type of micropalstics, their origin and fate of microplatics in marine environment as well as accumulation of other pollutants and heavy metals on MPs. In addition, MPs in marine environments undergo weathering/aging processes, which cause the degradation of MPs. The degradation mainly changes the physical properties of MPs which decides their distribution in ocean environment. Moreover, the ingestion of contaminated MPs by marine organisms may lead to the introduction of contamination to the marine organisms and food web and bring risks to marine organisms in any tropic level including algae to vertebrates such as fish, turtle and mammals including human being.

\section{References}

Andrady, A. L. (2017). The plastic in microplastics: A review. Marine Pollution Bulletin, 119(1), $12-22$.

Browne, M. A., Niven, S. J., Galloway, T. S., Rowland, S. J., \& Thompson, R. C. (2013). Microplastic moves pollutants and additives to worms, reducing functions linked to health and biodiversity. Current Biology, 23(23), 23882392.

Carr, S. A., Liu, J., \& Tesoro, A. G. (2016). Transport and fate of microplastic particles in wastewater treatment plants. Water Research, 91, 174-182.

Cedervall, T., Hansson, L. A., Lard, M., Frohm, B., $\&$ Linse, S. (2012). Food chain transport of nanoparticles affects behaviour and fat metabolism in fish. PloS One, 7(2), p.e32254.
Cole, M., Lindeque, P., Fileman, E., Halsband, C., \& Galloway, T. S. (2015). The impact of polystyrene microplastics on feeding, function and fecundity in the marine copepod Calanus helgolandicus. Environmental Science \& Technology, 49(2), 1130-1137.

Driedger, A. G., Dürr, H. H., Mitchell, K., \& Van Cappellen, P. (2015). Plastic debris in the Laurentian Great Lakes: a review. Journal of Great Lakes Research, 41(1), 9-19.

Edo, C., González-Pleiter, M., Leganés, F., Fernández-Piñas, F., \& Rosal, R. (2020). Fate of microplastics in wastewater treatment plants and their environmental dispersion with effluent and sludge. Environmental Pollution, 259, p.113837.

Eubeler, J. P., Zok, S., Bernhard, M., \& Knepper, T. P. (2009). Environmental biodegradation of synthetic polymers I. Test methodologies and procedures. TrAC Trends in Analytical Chemistry, 28(9), 1057-1072.

Green, D. S., Boots, B., O'Connor, N. E., \& Thompson, R. (2017). Microplastics affect the ecological functioning of an important biogenic habitat. Environmental Science \& Technology, 51(1), 68-77.

Guo, X., \& Wang, J. (2019). The chemical behaviors of microplastics in marine environment: A review. Marine Pollution Bulletin, 142, 1-14.

Hidalgo-Ruz, V., Gutow, L., Thompson, R. C., \& Thiel, M. (2012). Microplastics in the marine environment: a review of the methods used for identification and quantification.

Environmental Science \& Technology, 46(6), 3060-3075.

Jambeck, J. R., Geyer, R., Wilcox, C., Siegler, T. R., Perryman, M., Andrady, A., Narayan, R., \& 
Law, K. L. (2015). Plastic waste inputs from land into the ocean. Science, 347(6223), 768771.

Kühn, S., \& van Franeker, J. A. (2012). Plastic ingestion by the northern fulmar (Fulmarus glacialis) in Iceland. Marine Pollution Bulletin, 64(6), 1252-1254.

Lebreton, L. C., Van Der Zwet, J., Damsteeg, J. W., Slat, B., Andrady, A., \& Reisser, J. (2017).

River plastic emissions to the world's oceans. Nature Communications, 8, p.15611.

Li, J., Zhang, K., \& Zhang, H. (2018). Adsorption of antibiotics on microplastics. Environmental Pollution, 237, 460-467.

Lusher, A. L., Hernandez-Milian, G., Berrow, S., Rogan, E., \& O'Connor, I. (2018). Incidence of marine debris in cetaceans stranded and bycaught in Ireland: Recent findings and a review of historical knowledge. Environmental Pollution, 232, 467-476.

Müller, A., Becker, R., Dorgerloh, U., Simon, F. G., \& Braun, U. (2018). The effect of polymer aging on the uptake of fuel aromatics and ethers by microplastics. . Environmental Pollution, 240, 639-646.

O’Donovan, S., Mestre, N. C., Abel, S., Fonseca, T. G., Carteny, C. C., Cormier, B., Keiter, S. H., \& Bebianno, M. J. (2018). Ecotoxicological effects of chemical contaminants adsorbed to microplastics in the clam Scrobicularia plana. Frontiers in Marine Science, 5, p.143.

Prinz, N., \& Korez, Š. (2020). Understanding how microplastics affect marine biota on the cellular level is important for assessing ecosystem function: a review. In In YOUMARES 9-The Oceans: Our Research, Our Future (pp. 101120). Springer.

Reichert, J., Schellenberg, J., Schubert, P., \& Wilke, T. (2018). Responses of reef building corals to microplastic exposure. Environmental Pollution, 237, 955-960.

Schuyler, Q., Hardesty, B. D., Wilcox, C., \& Townsend, K. (2014). Global analysis of anthropogenic debris ingestion by sea turtles. Conservation Biology, 28(1), 129-139.

Sjollema, S. B., Redondo-Hasselerharm, P., Leslie, H. A., Kraak, M. H., \& Vethaak, A. D. (2016). Do plastic particles affect microalgal photosynthesis and growth? Aquatic Toxicology, 170, 259-261.

Thompson, R. C. (2015). Microplastics in the Marine Environment: Sources, Consequences and Solutions. In K. M. Bergmann M., Gutow L. (Ed.), Marine Anthropogenic Litter. Springer. https://doi.org/10.1007/978-3-319-16510-3_7

Thompson, R. C., Shanna, H. S., Charles, J. M., \& vom Saal Frederick, S. (2009). Our plastic age. Philosophical Transactions of the Royal Society B, 364, 1973-1976. http://doi.org/10.1098/rstb.2009.0054

Tosetto, L., Williamson, J. E., \& Brown, C. (2017). Trophic transfer of microplastics does not affect fish personality. Animal Behaviour, 123, 159-167.

Wright, S., R.C, T., \& TS, G. (2013). The physical impacts of microplastics on marine organisms: a review. Environmental Pollution, 178, 483492. 